石油技術協会誌 第 79 巻 第 1 号 （平成 26 年 1 月） $26 \sim 33$ 頁

Journal of the Japanese Association for Petroleum Technology

Vol. 79, No. 1 (Jan., 2014) pp. 26〜33

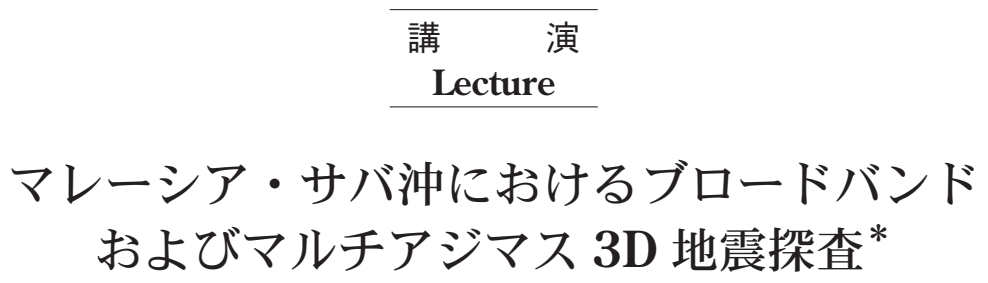

義山 智之***リー チー クン**

(Received September 5, 2013 ; accepted November 6, 2013)

\title{
Combination of broadband and multi-azimuth 3D seismic data acquisition in deep water Sabah, Malaysia
}

Tomoyuki Yoshiyama and Lee Chee Khoon

\begin{abstract}
Broadband acquisition and multi azimuth acquisition techniques in marine seismic survey are currently drawing considerable attention to improve the imaging for complex geology such as sub-basalt and sub-salt imaging.

In the Block DWR, offshore Sabah, Malaysia, complex toe-thrust structures are existing and conventional legacy seismic data over these structures is suffering the deterioration of imaging due to complexity of geology and existence of shallow amplitude anomalies.

JX Nippon Oil \& Gas Exploration (Deepwater Sabah) conducted 3D seismic survey with combination of broadband acquisition technique using slant streamer and multi-azimuth (two azimuth) acquisition technique over the Block DWR.

Broadband acquisition technique enhanced low frequency components in the seismic data and provided with improved imaging in toe-thrust structures and deeper seismic events. Processing for merged multi-azimuth seismic data is in progress, however, the seismic stack of each azimuth show better illumination than the other in different places. This fact indicates that merged azimuth seismic data can show better imaging and better seismic event continuities.
\end{abstract}

Keywords : broadband, multi-azimuth, low frequency, illumination

\section{1.はじめに}

近年の海洋地震探査において，上位の弾性波減衰層の影 響によるイメージング品質劣化の改善や地下深部のイメー ジング向上の手法としてブロードバンド収録が, 単一方向 （ナローアジマス）の収録ではイメージングが困難な複雑 な地質構造に対するイルミネーション向上手法として, マ ルチアジマス, ワイドアジマス, リッチアジマス，コイル シューティングなどの手法が注目を集めており，それぞれ サブバサルトやサブソルトなどのイメージングに適用され ている。

JX 日鉱日石サバ深海石油開発(侏)（以下，JX 開発）がオ ペレーターとして探鉱活動を行っているマレーシア・サバ 沖深海 DWR 鉱区（図 1) およびその周辺地域では, 中新 世おける圧縮応力場および重力性すべりによって形成され

*平成 25 年 6 月 27 日平成 25 度年春季講演会地質・探鉱部門シンポジウ 厶「課題は果たされたのか? 一物理探査技術の現況と将来一」にて講演 This paper was presented at the 2013 JAPT Geology and Exploration Symposium entitled "Geophysical Exploration Technology, Present Status and Next Generation" held in Tokyo, Japan, on June 27, 2013.

** JX 日鉱日石サバ深海石油開発侏) JX Nippon Oil \& Gas Exploration（Deepwater Sabah) Limited
たトウスラスト構造が卓越し, 北東一南西方向の衝上断層 帯を形成している。

DWR 鉱区における 2001 年収録の既存 $3 D$ 地震探鉱記録 では，浅部ガスによるものと考えられる振幅異常域の下部 におけるイメージング品質劣化, 深部構造のイメージング 品質不良, また複雑なトウスラスト構造内部のイメージン グ品質不良が問題となっていた（図 2)。そこで, JX 開発 は本鉱区においてブロードバンド収録技術とマルチアジマ

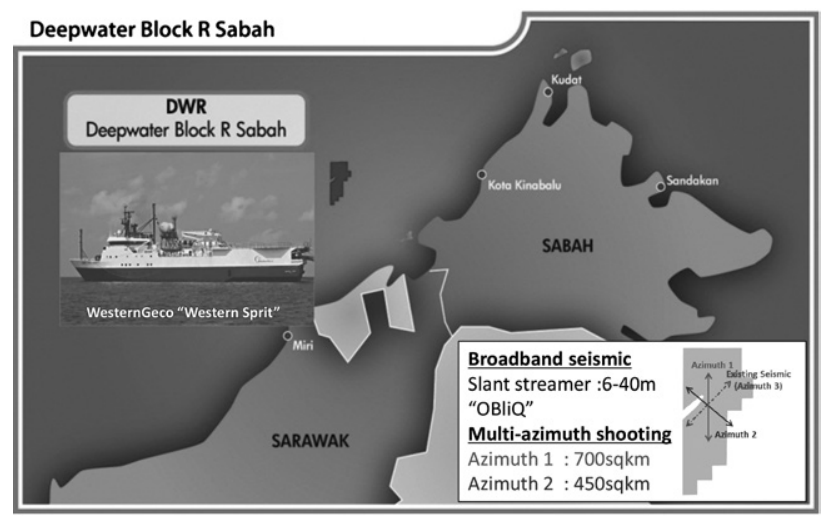

図 1 DWR 鉱区位置図 

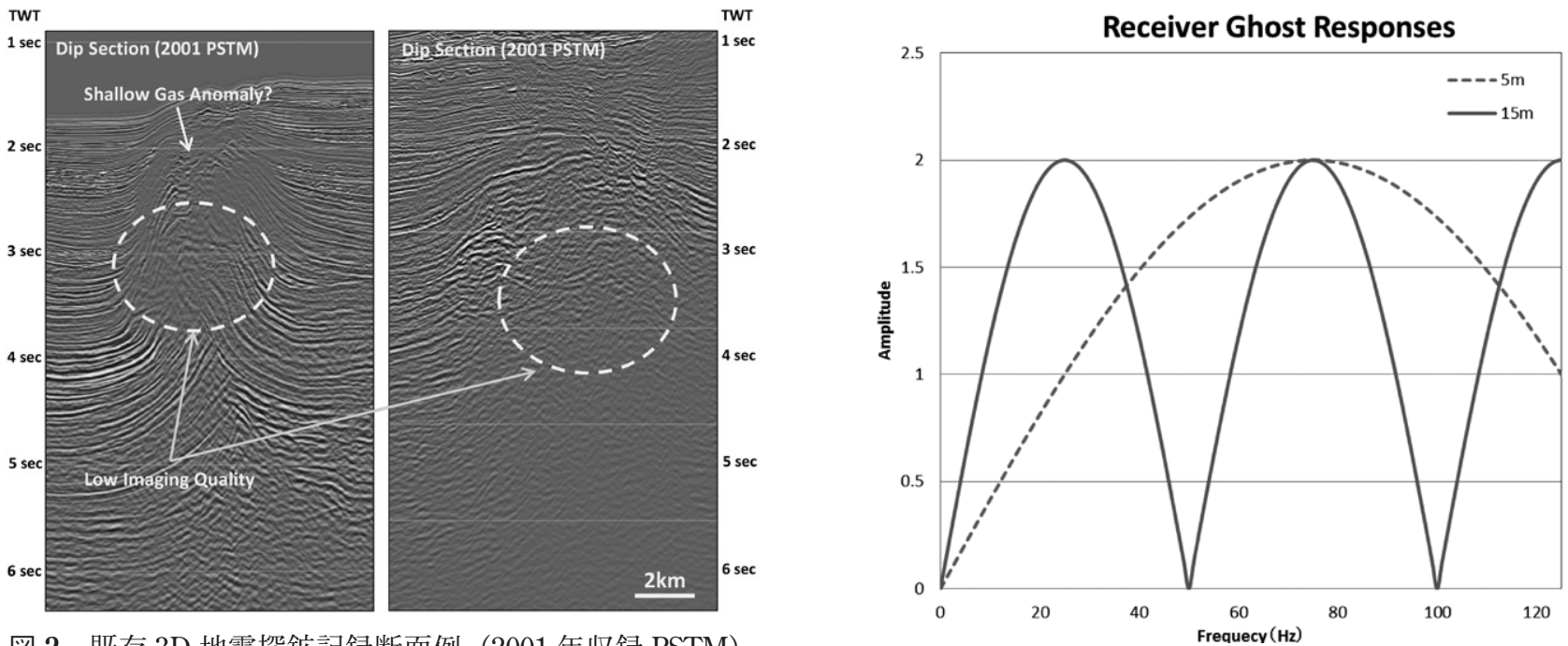

図 2 既存 3D 地震探鉱記録断面例（2001 年収録 PSTM）

図 3 ストリーマー深度の違いによるゴーストレス ポンス (5 $\mathrm{m}$ および $15 \mathrm{~m})$

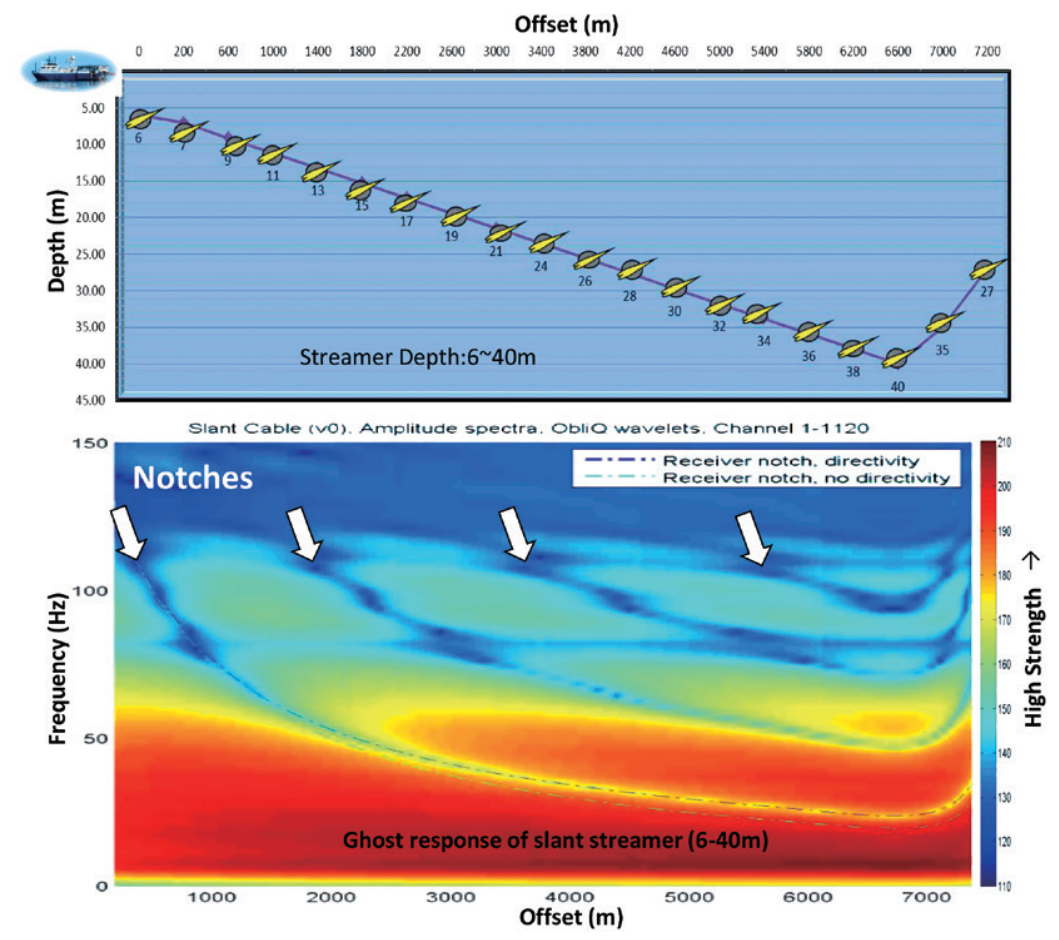

図 4 スラントストリーマーのゴーストレスポンス
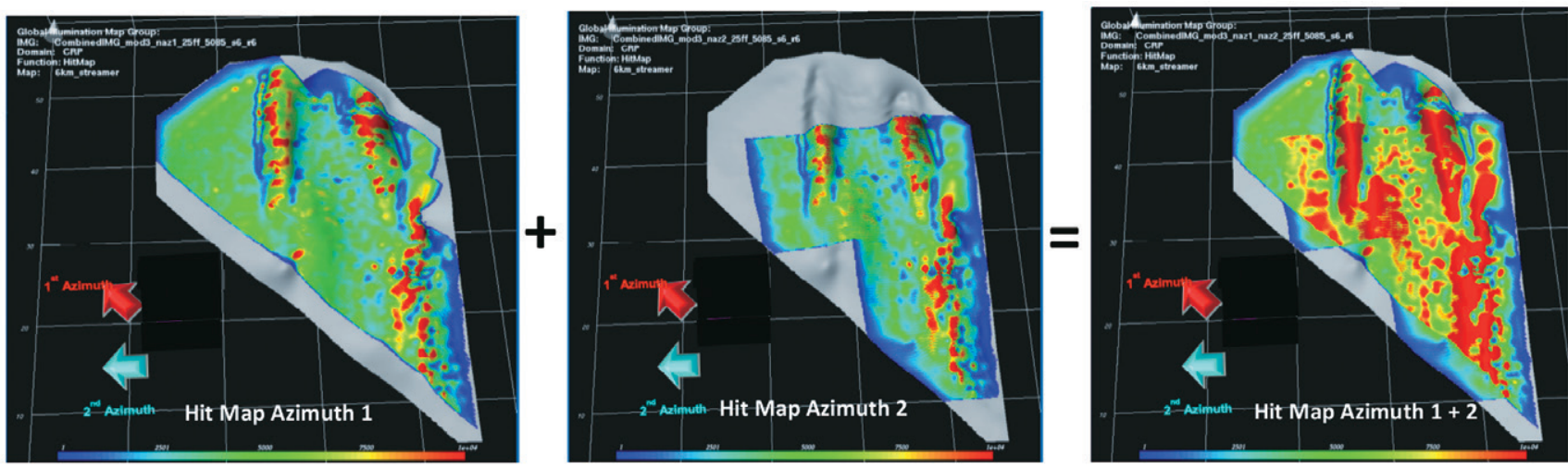

図 5 アジマス 1 および 2 におけるヒットマップヒット

マップにおいて構造部における効果的なイルミネーションが期待できる。 
ス収録技術を組み合わせた $3 \mathrm{D}$ 地震探査を実施した。ブロー ドバンド収録による弾性波エネルギーの深部への透過性の 向上, マルチアジマス収録による複雑構造のイルミネー ションの向上によって, 前述の既存 $3 \mathrm{D}$ 地震探鉱記録の問 題の改善が期待できる。

なお，本地震探鉱記録の処理作業は本稿執筆時点で継続 中であり, 後半に示す各アジマスの地震探鉱記録断面は重 合前時間マイグレーション（以下，PSTM）のファストト ラック，およびアジマス統合処理前のものである。

\section{2. ブロードバンド収録技術}

海洋における地震探査において, 収録デー夕の周波数帯 域が制限される大きな要因の 1 つとしてゴーストの存在が 挙げられる。ゴーストには, 弾性波が海水面で反射した下 向波が受振器で収録される受振器側ゴーストと, 震源から 発生させた弾性波が直接海水面で反射した後にある波線経 路を経て受振器で収録される震源側ゴーストがあり, 一次 反射波と重なって収録データの振幅スペクトルにノッチを 発生させる。通常の一定深度でのストリーマー曳航および 単一深度の震源での収録では, ストリーマー深度または震 源深度に依存した周波数域にノッチが発生し,このノッチ 周波数において収録データのスペクトル強度が抑制され る。図 3 にストリーマー深度が $5 \mathrm{~m}$ および $15 \mathrm{~m}$ の場合の 理想的なノイズを含まない受振器側ゴーストレスポンスを 示す。ストリーマー深度を深くした場合, 波浪ノイズなど の低周波ノイズはある程度回避できるが，振幅スペクトル における最初のノッチ周波数が低くなり高周波数成分が損 なわれてしまう。反対に, ストリーマー深度を浅くした場 合は最初のノッチ周波数が高くなり, 高周波成分は確保で きるものの, $0 \mathrm{~Hz}$ におけるノッチの影響により低周波数 成分が損なわれてしまう。また, 浅い深度のストリーマー では波浪ノイズなどの低周波ノイズの影響を強く受けてし まう。このように, 一定深度のストリーマー曳航による収 録では, 曳航深度によって収録周波数帯域は制限を受け, 高周波数成分と低周波数成分の確保は互いにトレードオフ の関係となる。この関係は, 震源側についても同様である。 ここで取り上げるブロードバンド収録技術は，収録ジオメ トリの工夫やマルチセンサーの使用などによってゴースト を抑制し, 収録デー夕の広帯域化を図るものであり, 手 法は異なるものの, WesternGeco 社, CGGVeritas 社, PGS 社などの物理探査会社によって実用化されている。収録 データの広带域化によって, 基本波形のサイドローブが抑 制され，地震探鉱記録の高分解能化ができる。また，特に 低周波数帯域の拡張によって弾性波エネルギーの深部への 透過性が高まり, 深部のイメージングの向上が期待できる。

本鉱区におけるブロードバンド収録技術としては,

WesternGeco 社のスラントストリーマーを利用した ObliQ および 2 つの異なる深度で発震する震源システムを採用 した。

ObliQ ではストリーマーを線形に傾斜させて曳航（スラ ントストリーマー) することで，ノッチ周波数をオフセッ
トごとにスライディングさせ (図 4), 受振器側ゴースト によるノッチの影響を分散させる。これにより，収録され るデー夕の低周波数帯域および高周波数帯域が拡張され， 通常の収録と比較して広周波数帯域の収録が可能となる。 今回の地震探査においてはニアオフセットからファーオフ セットにかけて $6 \mathrm{~m}$ から $40 \mathrm{~m}$ にストリーマーを傾斜させ て収録を行った。ストリーマー後部では, テイルブイとの 接続ため $\mathrm{V}$ 字型の形態にしている。

スラントストリーマーでの収録に加え，異なる 2 つの水 深で発震を行うことで, 震源側ゴーストによるノッチ周波 数の影響の軽減も図った。3 列のサブアレイから成る震源 において外側の 2 列のサブアレイの震源を $6 \mathrm{~m}$, 中央のサ ブアレイの震源 $12 \mathrm{~m}$ の深度に配置した $\mathrm{V}$ 字型の震源配置 を採用した。1 $12 \mathrm{~m}$ の震源においては約 4 ミリ秒の遅延発 震をすることによって, $6 \mathrm{~m}$ および $12 \mathrm{~m}$ の震源からの下 向波のエネルギーは増幅されるに対し, ゴーストのエネル ギーは分散される。この 2 つ深度での発震による震源波形 の振幅スペクトルにおいては, 通常の単一深度の震源と比 較して周波数帯域が拡張されるが, 今回の場合 $12 \mathrm{~m}$ の震 源深度に対応したノッチ周波数におけるスペクトル強度が 通常の単一深度の震源のときよりも小さくなるという特徵 がある (Cambois et al., 2009)。

\section{3. マルチアジマス収録技術}

構造系列の走向方向にて発震・収録された $3 \mathrm{D}$ 地震探鉱 記録におけるトウスラスト構造の内部のイメージング品質 不良は, 浅部に見られる振幅異常域の影響だけでなく, 構 造自体の複雑さやクロスライン方向のサンプリング不足 に起因したイルミネーション不良が原因の 1 つと考えられ た。海洋 $3 \mathrm{D}$ 地震探査における通常の単一方向での収録で は, 波線経路の方位およびオフセットが一定方向に限定さ れてしまう。対象層やその上位層の構造形態が複雑な場合, この一定方向に限定された波線経路だけでは, 十分なイル ミネーションが得られず適切なイメージングができないこ とがある。このような複雑構造に対するイメージング手法 として, 多様な波線経路を確保したマルチアジマス, ワイ ドアジマス, リッチアジマス, コイルシューティングなど が用いられる。

今回の地震探査では南北方向（構造系列の傾斜方向と走 向方向の中間）をアジマス 1 , 構造の傾斜方向をアジマス 2 として計 2 方向でのマルチアジマス収録を実施した（図 1)。収録方向に関しては, シミュレーションにおいてトウ スラスト構造が効果的にイルミネーションできることを 確認し, アジマス 1 には最も効果的に収録が可能な南北方 向を選択した。図 5 にアジマス 1 およびアジマス 2 におけ るヒットマップを示す。ヒットマップはターゲット層のあ るビンにおける弾性波の反射回数を示しており, 反射回数 が少ない部分は $\mathrm{S} / \mathrm{N}$ 比が低いことが予想できる。今回の アジマス 1 およ゙アアジス 2 による収録では，構造部にお いて効果的なイルミネーションが得られることが期待でき た。当初, アジマス 1 およびアジマス 2 に加え, 走向方向 
表 1 収録パラメーター

\begin{tabular}{|l|l|}
\hline Content & Specification \\
\hline Streamer & \\
\hline Number of streamers & 8 \\
\hline Streamer length & $7,200 \mathrm{~m}$ \\
\hline Streamer depth & Slanted from 6 (Near) to 40 (Far) m \\
\hline Streamer separation & $100 \mathrm{~m}$ \\
\hline Nearest offset & $140 \mathrm{~m}$ \\
\hline Receiver & \\
\hline Receiver interval & $6.25 \mathrm{~m}$ \\
\hline Recording length & $8,192 \mathrm{~ms}$ (sampling rate : 2 ms) \\
\hline Source & \\
\hline \multirow{2}{*}{ Number of sources } & 2 \\
\hline Source depth & a source consists of 3 sub-array \\
\hline Source separation & $50 \mathrm{~m}$ \\
\hline Source volume (cu.in) & 5,085 cu.in (Sub-array : 1695cu. in) \\
\hline Shot point interval & flip-flop 25 m \\
\hline
\end{tabular}

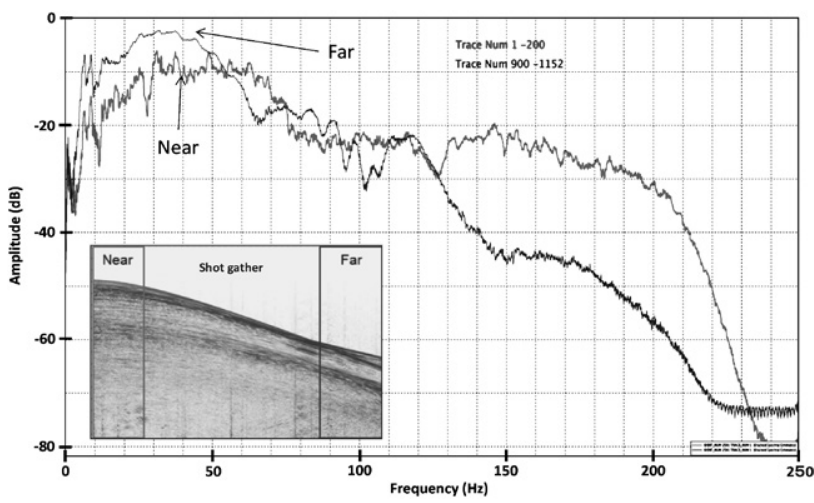

図 6 実際のショットギャザーのニアオフセットと ファーオフセットの振幅スペクトル

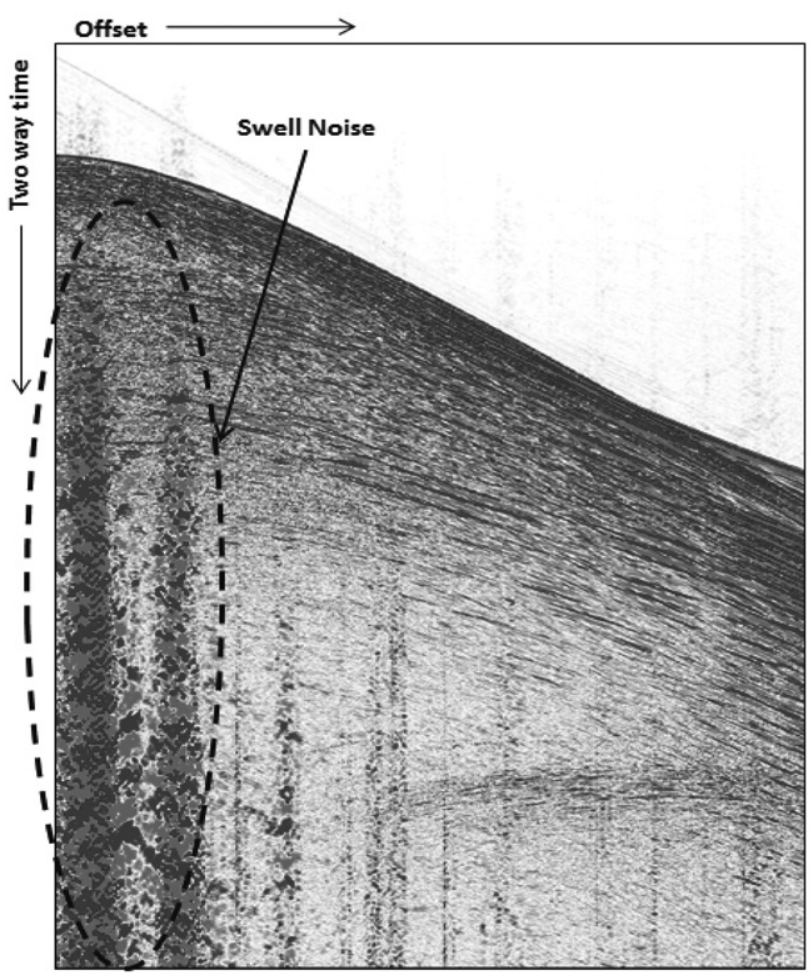

図 7 実際の悪天候時のショットギャザー
のアジマス 3 の収録も実施する予定であつたが，収録期間 の制約のためにアジマス 3 の収録は見送られた。後述する が，当初予定のアジマス 3 の代替として既存 3D 地震探鉱 記録の再処理結果をアジマス 3 として統合することを計画 し (本稿執筆時点で処理未完了), 処理テストのために既 存 3D 地震探鉱記録の収録方向と同方向の $2 \mathrm{D}$ ラインをテ ストラインとして数本収録することとした。

\section{4. 収録}

2012 年 7 月から 9 月にかけて, WesternGeco 社の地震 探査船 Western Sprit よってアジマス 1 およびアジマス 2 の合計約 1,150 Full-fold $\mathrm{km}^{2}$ のブロードバンドおよびマル チアジマス複合 $3 \mathrm{D}$ 地震探査を実施した。収録パラメーター を表 1 に示す。収録パラメーターは事前に実施したイルミ ネーションスタディによって決定した。既存 $3 \mathrm{D}$ 地震探鉱 記録解釈に基づき地下構造および浅部ガスゾーンを $3 \mathrm{D}$ モ デル化し，シミュレーションによって各種パラメーターが 収録周波数帯域や解像度に与える影響，および前述のマ ルチアジマス収録における各アジマスのイルミネーショ ン（ターゲット層のヒットマップや振幅值シミュレーショ ン）に与える差異を比較検討した。収録作業においては, ストリーマーを水中で傾け保持する技術や，水深の異な る 2 つの震源の発震タイミングの管理などブロードバンド 収録特有の高度な技術が用いられた。また, 収録システム として WesternGeco 社の Q-marine システムを採用した。 Q-marine システムは主に，ストリーマーにおける $3.125 \mathrm{~m}$ 間隔のポイント受振器システム, ストリーマーに取り付け られた上下方向および水平方向に操縦可能なフィンによる ストリーマー操縦システム, 高密度の音響測位ネットワー クによるストリーマー位置管理システム, 発震ごとの震源 波形の推定システムなどから構成され, 収録作業の効率 化，地震探鉱記録の品質向上および広帯域化に寄与してい る（大澤ほか，2006）。図 6 に実際のショットギャザーに おけるニアオフセットとファーオフセットの振幅スペクト ルの比較を示す。図中では, ストリーマー深度の深いファー オフセット側では低周波数成分が卓越していることが分か る。ストリーマー深度の浅いニアオフセット側では, 高周 波数成分が卓越しているが，実際には高周波の多重反射波 ノイズ等の影響を受けており, 単純な比較には注意が必要 である。図 7 に悪天候時のショットギャザーを示す。スト リーマー深度の深いファーオフセットにおいてはニアオフ セットで確認できる悪天候による波浪ノイズの影響を受け ずに収録されている。

\section{5. 処 理 結果}

\section{1 ブロードバンド}

WesternGeco 社の処理プロセスにおいて ObliQ によって 収録されたデータは Single Streamer De-ghosting（以下, SSD）と呼ばれる処理によって，プリスタックの段階で受 振器側ゴーストを分離・除去し, 理想的な広帯域の地震探 鉱記録を得る。SSD について開示されている情報は少な 

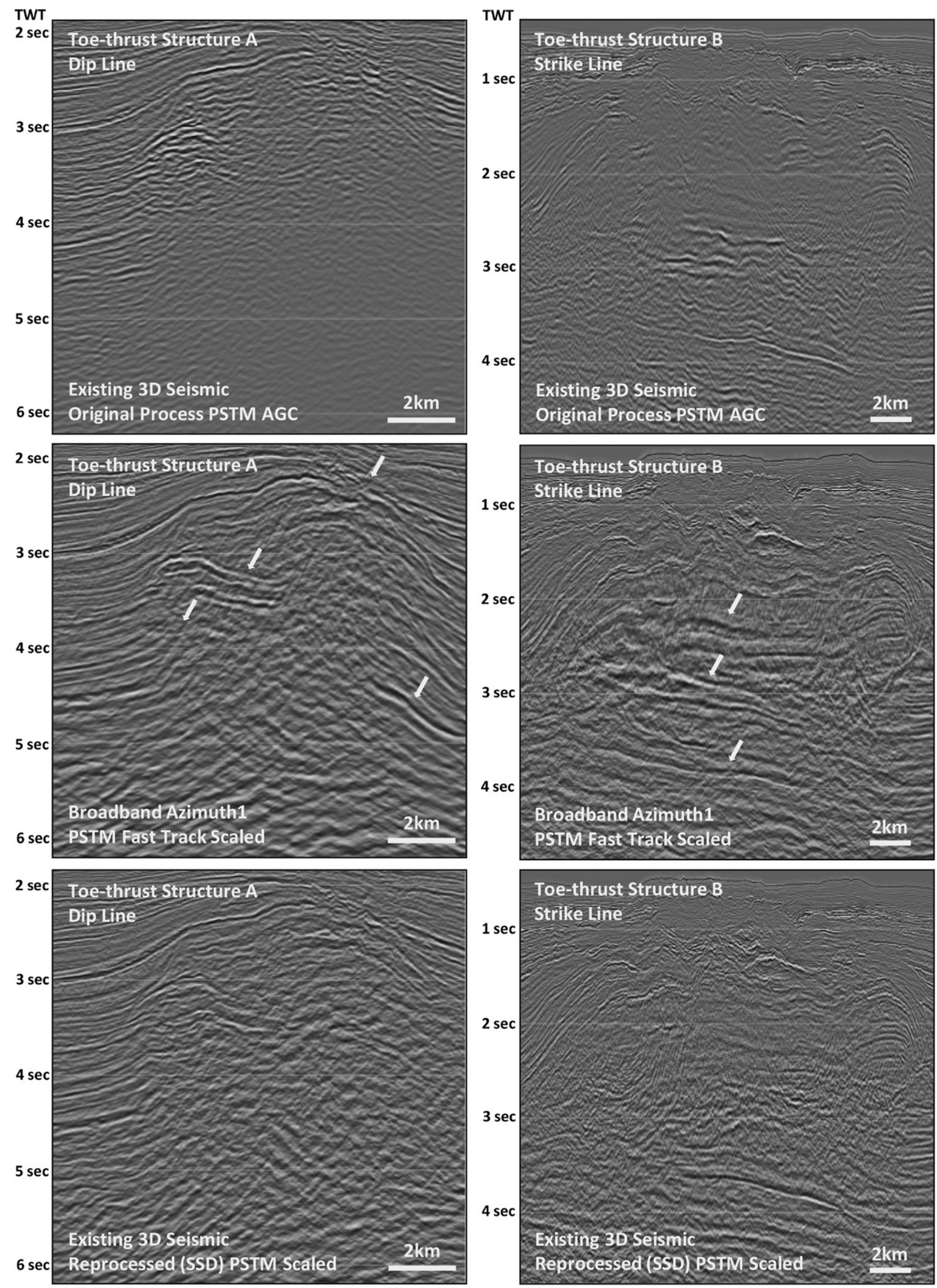

図 8 地震探鉱記録断面の比較

上段 : 既存 $3 \mathrm{D}$ 地震探鉱記録オリジナル処理，中段 : ブロードバンド $3 \mathrm{D}$ 地震探鉱記録・アジ マス 1 , 下段 : 既存 $3 \mathrm{D}$ 地震探鉱記録再処理 $(\mathrm{SSD})$ 

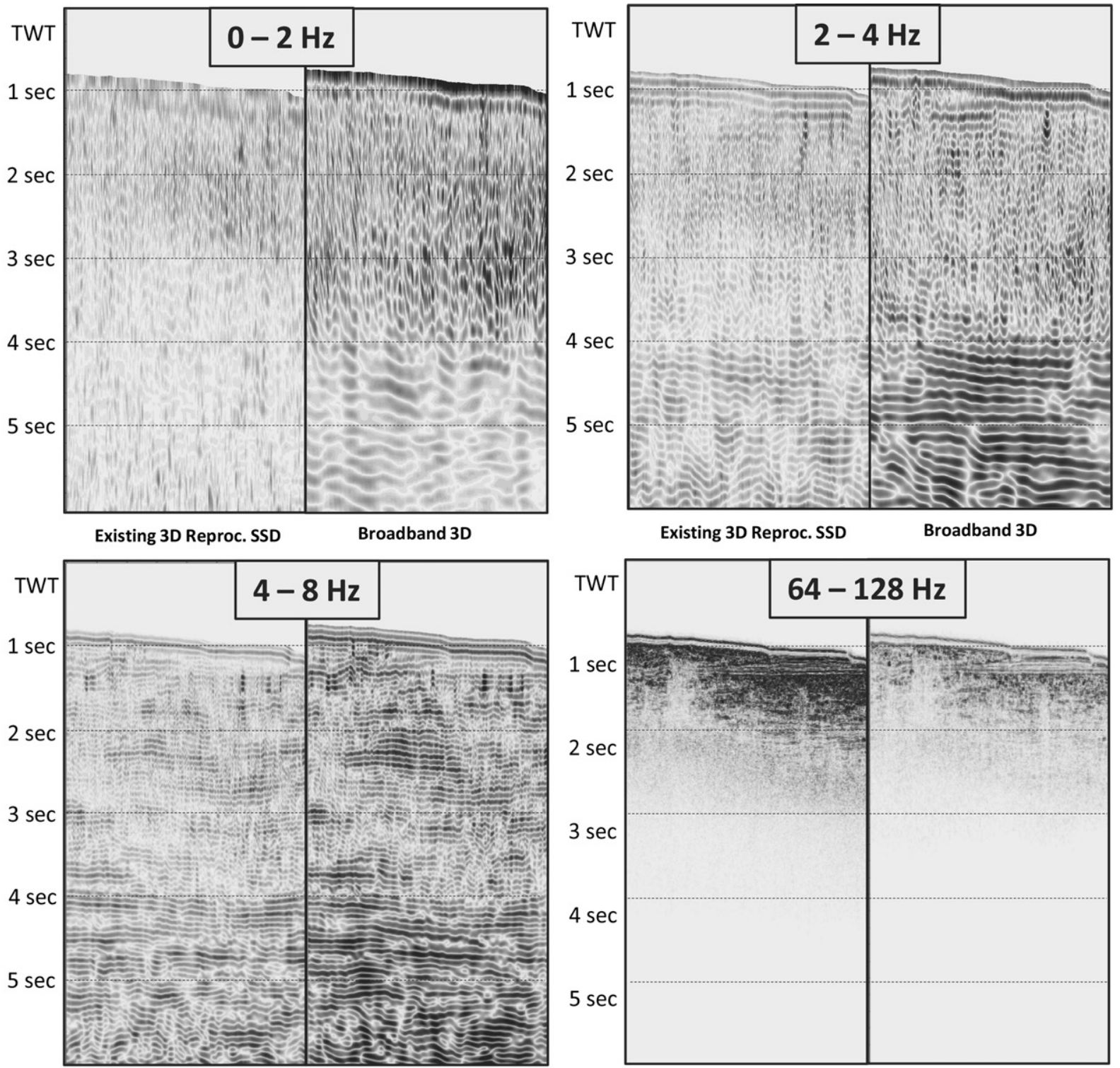

Existing 3D Reproc. SSD

Broadband 3D

Existing 3D Reproc. SSD

Broadband 3D

図 9 バンドパスフィルターパネル

左側 : 既存 3D 地震探鉱記録再処理（SSD），右側 : ブロードバンド 3D 地震探鉱記録・アジマス 1（振幅は標準化）

いが, Spectral reconstruction の一種として紹介され（Moldoveanu et al., 2012), 未知パラメーターとなるゴーストが 除去されたデー夕（上向波）のスペクトルをインバージョ ン問題として解くとしている。SSD はブロードバンド収 録でない通常の地震探鉱記録に対しても適用可能であり, 既存 3D 地震探鉱記録の再処理として, SSD を含夕今回の ブロードバンド3D 地震探鉱記録と同等の処理を実施した。

図 8 に今回のブロードバンド $3 \mathrm{D}$ 地震探鉱記録（アジマ ス 1， PSTM・ファストトラック)，既存 $3 \mathrm{D}$ 地震探鉱記録 オリジナル処理および既存 $3 \mathrm{D}$ 地震探鉱記録再処理（ファ ストトラック）断面の比較を示す。ブロードバンド収録に よる地震探鉱記録断面は，他の 2 つの断面と比較して， ト ウスラスト構造内部，深部構造，断層面のイメージングな ぞイベントの連続性・イメージング品質が改善しているこ とがわかる（図 8 中，矢印で示される部分)。既存 $3 \mathrm{D}$ 地 震探鉱記録の収録・処理パラメーターは，ブロードバンド
収録・処理以外のパラメーターも今回の地震探査とは異な るため, 単純には比較できないものの, ブロードバンド収 録・処理による低周波数帯域の拡張, 弾性波エネルギーの 透過性の向上がこれらの記録品質改善に寄与しているもの と考えられる。SSD を実施した既存 $3 \mathrm{D}$ 地震探鉱記録の再 処理断面においても, 深部イメージング品質やイベントの 連続性に改善が見られる。

図 9 に今回のブロードバンド 3D 地震探鉱記録断面と既 存 3D 地震探鉱記録再処理断面のバンドパスフィルターパ ネルを示す。 $2-4 \mathrm{~Hz}$ および $4-8 \mathrm{~Hz}$ のバンドパスフィルター パネルにおいて, 特に 4 秒以深でのブロードバンド $3 \mathrm{D}$ 地 震探鉱記録の方に, 強いシグナルのエネルギーが確認で きる。今回の結果では, 地震探鉱記録の低周波数帯域の 拡張にはブロードバンド処理（SSD）だけでなく，ブロー ドバンド収録が不可欠であったことが分かる。一方で, 64-128 Hz のバンドパスフィルターパネルにおいては, 特 

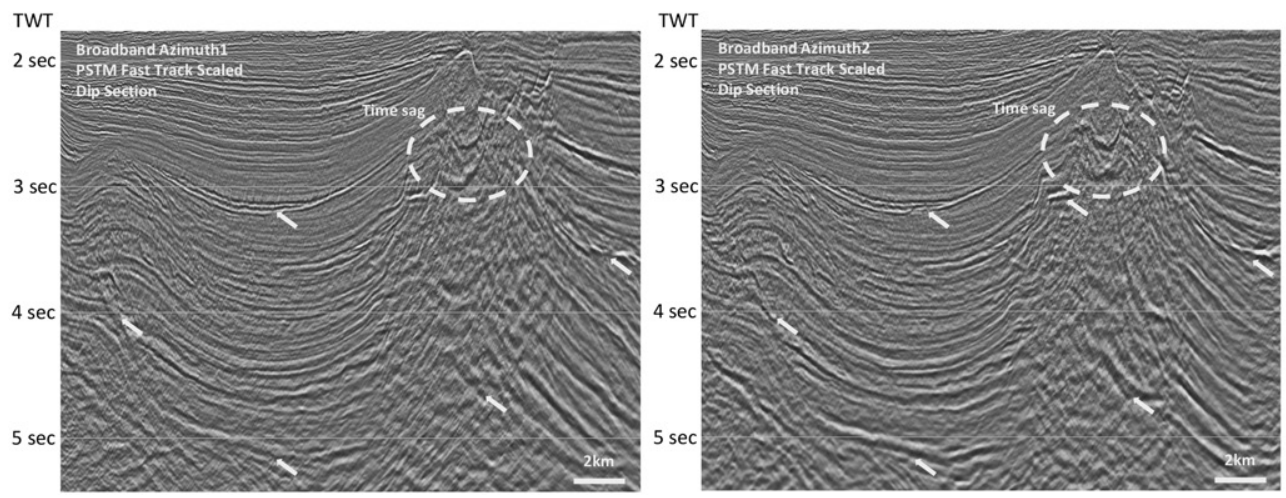

図 10 アジマス 1 およびアジマス 2 地震探鉱記録断面の比較 左側 : アジマス 1 , 右側 : アジマス 2

に浅部で既存 3D 地震探鉱記録の方が，エネルギーが大き いことが確認できる。考察には最終処理結果を待たなくて はならないが, スラントストリーマーによる収録では高周 波数成分がニアオフセットでしか収録されないために全体 として高周波数のスペクトル強度が落ちること, 既存 $3 \mathrm{D}$ 地震探鉱収録では除去しきれていない高周波のノイズが 残っていることなどが可能性として考えられる。

\section{2 マルチアジマス}

アジマス 1 とアジマス 2 は, セクタースタックとして別々 に処理された後にアジマス統合スタック処理がなされる （ただし, マイグレーション処理においては共通の速度デー タが用(られる)。このアジマス統合スタック処理は Optimum Weighted Stack（以下，OWS）と呼ばれる。OWSに おいて，アジマス 1 とアジマス 2 は単純に加算・平均化さ れるのではなく, 各アジマスにて空間・時間方向の震探イ ベントの連続性またはイルミネーションの良好な部分がよ
り反映されるよう重み付けが計算され，この重夕付けに基 づいてアジマス統合スタックが作成される (Cooke et al. 2011)。

本稿執筆時点では OWS の処理は未完了であるが，アジ マス 1 およびアジマス 2 のそれぞれの処理結果の比較から OWS の効果がある程度予見できると考えられる。図 10 に アジマス 1 およびアジマス 2 , それぞれ同位置での地震探 鉱記録断面の比較を示す。図 10 ではアジマス 1 およびア ジマス 2 それぞれにおいて他方よりも震探イベントの連 続性の良好な部分が確認できる（図 10 中, 矢印で示され る部分)。また, 震探イベントの連続性が良好な部分では 振幅が大きくなると仮定し, あるホライズン（ホライズ ンA）の上位および下位に 20 ミリ秒のウィンドウを設定 してアジマス 1 およびアジマス 2 の地震探鉱記録に対して RMS 振幅を計算した。図 11 に前述のアジマス 1 の RMS 振幅とアジマス 2 の RMS 振幅の差をとつたものを示して

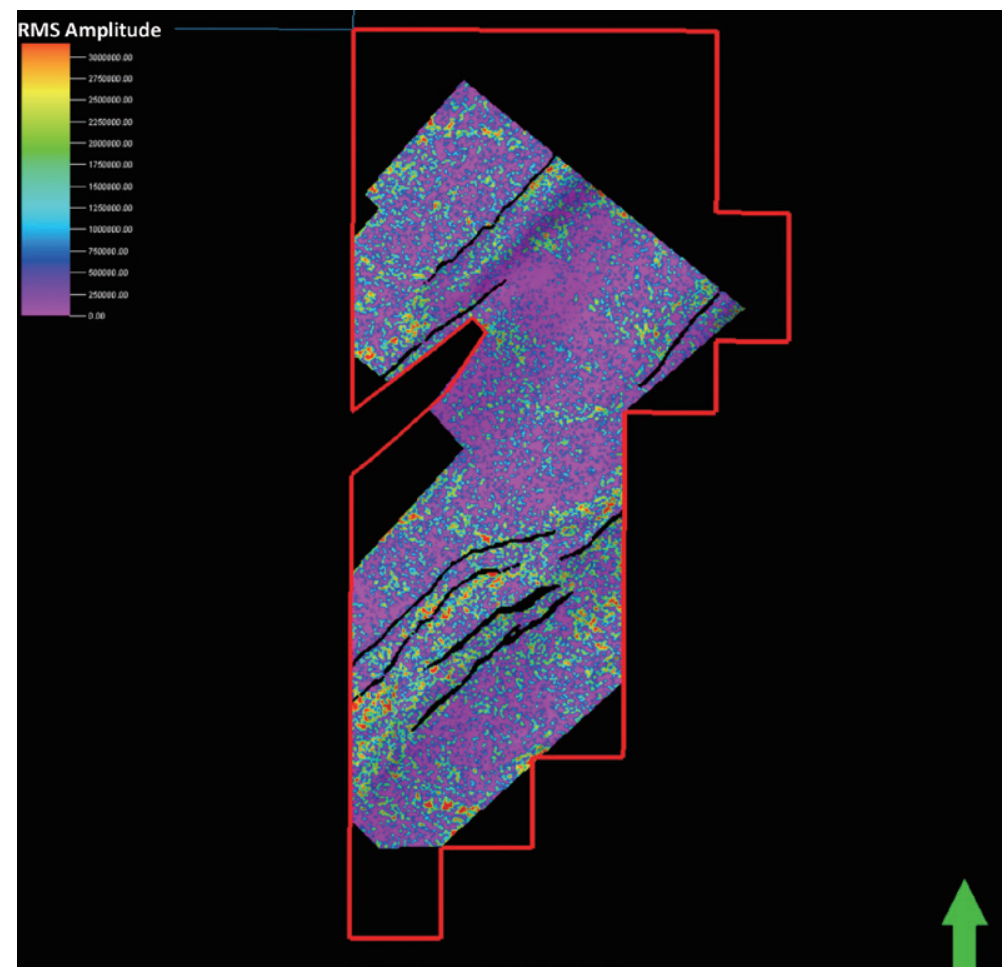

図 11 アジマス 1 およびアジマス 2 における RMS 振幅値（ホライズン A $\pm 20 \mathrm{~ms}$ ）の差 

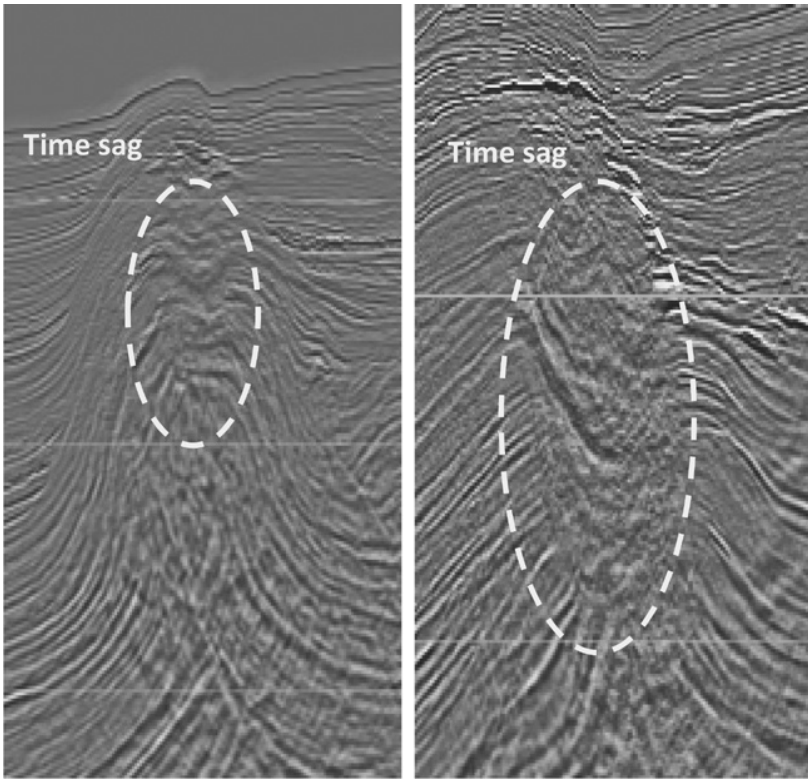

図 12 地震探鉱記録断面（ブロードバンド）における 震探イベントのプルダウン（Time sag） 左側 : 構造頂部に見られるプルダウンの例 1 , 右側 : 構造頂部に見られるプルダウンの例 2

いる。高い值を示している部分はアジマス 1 とアジマス 2 の RMS 振幅の差が大きい部分であり，震探イベントの連 続性やイルミネーションに優劣の差がある部分と捉えるこ とができる。これらの部分において OWS における重み付 けの効果が発揮され, 多くの部分で OWS 後の震探イベン トの連続性およびイルミネーションの改善がなされると考 えられる。

\section{6. まとめと今後の展望}

ブロードバンド収録および処理によって, 特に低周波数 成分の拡張，弾性波エネルギーの透過性の向上がなされ， トウスラスト構造内部および深部のイメージング品質を改 善することができた。この品質改善は地震探鉱記録のより 正確な解釈の助けとなるだけでなく，低周波数帯域の拡張 によって，インバージョン処理における低周波数モデル構 築の際の利点にもなる。また，マルチアジマス収録の各ア ジマスにおいて，他方のアジマスと比較して良好なイベン 卜連続性を持つ部分が確認できた。今後の処理において, 各アジマスの震探イベント連続性の良好な部分が反映され た効果的なアジマス統合スタックが得られると期待できる。

一方で，ブロードバンド収録において浅部ガスなどに よる振幅異常域下位の弾性波の透過性は向上したと考え られるものの，アジマス 1 およびアジマス 2 とも浅部ガ スと考えられる振幅異常域下位の震探イベントのプルダ ウンが残った（図 10 および 12 において点線で囲まれた部
分）。このような震探イベントのプルダウンの補正として, Anisotropic 重合前深度マイグレーション処理を予定して おり，震探イベントのプルダウンによって歪められた構造 のより正確なイメージングが期待できる。振幅異常域下位 の震探イベントのプルダウンへの対応として, 同様の処理 が DWR 鉱区近傍の Kikeh 油田にて適用され，その成果が 報告されている（Khan et al., 2005）。

また，今回のマルチアジマス収録では構造系列の傾斜方 向と走向方向の中間にあたるアジマス 1 と構造系列の傾斜 方向のアジマス 2 のタが収録され，当初計画された走向方 向のアジマス 3 の収録はできなかつた。そこで，構造系列 の走向方向に収録された既存 $3 \mathrm{D}$ 地震探鉱記録をアジマス 3 としてアジマス統合スタックに組み込むことを計画して おり，アジマス 1 からアジマス 3 の各アジマスに対して前 述のAnisotropic 重合前深度マイグレーション処理適用後, OWS 処理が実施される。ブロードバンド収録がされてお らず，またアジマス 1 とアジマス 2 とは振幅スペクトルが 異なるアジマス 3 をどのように適切に処理, 統合していく かが今後の課題となる。

\section{謝 辞}

資料の公表を許可していただいたペトロナス, 国際石油 開発帝石(株)，JX 日鉱日石開発(株に深謝いたします。

\section{引用 文 献}

Cambois, G., Long, A., Parkes, G., Lundsten, T., Mattsson, A. and Fromyr, E., 2009 : Multi - Level airgun array: A simple and effective way to enhance the low frequency content of marine seismic data. SEG Technical Program Expanded Abstracts 2009, 152-156.

Cooke, A., Moreira, L., Garrity, J., Luthy, S., Silva, P. and Hsaio, H., 2011 : High-resolution multiazimuth towed-streamer Seismic acquisition and processing - A case study from the Campos Basin offshore Brazil. 12th International Congress of the Brazilian Geophysical Society, Extended abstract.

Khan, O. and Klein-Helmkamp, U., 2005 : Deepwater imaging beneath gas anomalies - A case study. 67th EAGE Conference \& Exhibition, Extended abstracts, B029.

Modoveanu, N., Seymour, N., Manen, D.J. and Caprioli, P., 2012 : Broadband seismic methods for towed-streamer acquisition. 74th EAGE Conference \& Exhibition, Extended abstracts, Z009.

大澤 理・アルディラロドルフォ, 2006：Qマリーンの最 新技術およびケーススタディー. 物理探査学会第 114 回 学術講演会論文集, 53-56. 